IZA DP No. 5969

Then and Now:

Reflections on Two Australian Mining Booms

Robert G. Gregory

September 2011

Forschungsinstitut zur Zukunft der Arbeit Institute for the Study of Labor 


\title{
Then and Now: Reflections on Two Australian Mining Booms
}

\author{
Robert G. Gregory \\ Australian National University, Victoria University, \\ Queensland University of Technology and IZA
}

Discussion Paper No. 5969

September 2011

\author{
IZA \\ P.O. Box 7240 \\ 53072 Bonn \\ Germany \\ Phone: +49-228-3894-0 \\ Fax: +49-228-3894-180 \\ E-mail: iza@iza.org
}

\begin{abstract}
Any opinions expressed here are those of the author(s) and not those of IZA. Research published in this series may include views on policy, but the institute itself takes no institutional policy positions.

The Institute for the Study of Labor (IZA) in Bonn is a local and virtual international research center and a place of communication between science, politics and business. IZA is an independent nonprofit organization supported by Deutsche Post Foundation. The center is associated with the University of Bonn and offers a stimulating research environment through its international network, workshops and conferences, data service, project support, research visits and doctoral program. IZA engages in (i) original and internationally competitive research in all fields of labor economics, (ii) development of policy concepts, and (iii) dissemination of research results and concepts to the interested public.
\end{abstract}

IZA Discussion Papers often represent preliminary work and are circulated to encourage discussion. Citation of such a paper should account for its provisional character. A revised version may be available directly from the author. 
IZA Discussion Paper No. 5969

September 2011

\title{
ABSTRACT \\ Then and Now: \\ Reflections on Two Australian Mining Booms*
}

\begin{abstract}
Australia is experiencing its largest mining boom for more than a century and a half. This paper explores, from a national perspective, important economic differences that arise when a mining boom, such as the current one, is generated by export price increases (trading gains) rather than export volume increases. Terms of trade changes - through their direct trading gain effect and indirect real GDP effect, primarily through increased employment levels - have increased Australian living standards. The increase, relative to the US, is about 25 per cent; an increase which probably places Australian living standards well above those of the US.
\end{abstract}

JEL Classification: Q33, O11, E01, O47, C43

Keywords: resource booms, terms of trade, real GDP, economic growth

Corresponding author:

Bob Gregory

Economics Program

Research School of Social Sciences

Australian National University

Canberra ACT 0200

Australia

E-mail: bob.gregory@anu.edu.au

\footnotetext{
* I have benefited from presentations at Columbia University and the University of Wisconsin. I have had wide ranging discussions with Rob Bray, Peter Sheehan, Tue Gorgens and Bob Haveman. These good friends have helped a great deal and hopefully, given that there are still so many loose ends in these reflections, they will continue to discuss these issues with me in the future. An early version was prepared for the Feb.2011 Conference "Resource Boom; Understanding the National and Regional Implications" at Victoria University, Melbourne.
} 


\section{Introduction}

I was extremely pleased to be invited to contribute reflections on the current mining boom on the $35^{\text {th }}$ anniversary of the publication of "Some Implications of the Development of the Mining Sector" (the mineral paper) in the Australian Journal of Agricultural Economics, 1976. The mineral paper provided the dominant intellectual framework for analyzing the resource reallocation and exchange rate implications of the 1970's mineral boom.

The mineral paper, responding to the 1970s economic environment was designed with two purposes in mind. One purpose was to increase understanding of the potential effects of two policy instruments that had not generally been used in Australia - a large across-the-board tariff cut and changes in the nominal exchange rate. ${ }^{2}$ The other purpose was to increase understanding of the relationship between the development of the new mineral export sector and the large structural breaks that were occurring in the Australian economy. The new export sector was generating significant changes in the price ratio of traded to non-traded goods and, in this way, crowding out old export industries, primarily rural products, and industries which competed with imports. The structural breaks, produced by this change in comparative advantage, were most evident in the relative decline of manufacturing output and the subsequent and dramatic fall in the male fulltime employment-population ratio that continued for the next two decades. ${ }^{3}$ A sectoral resource competition - real exchange rate framework is now reasonably well understood

\footnotetext{
${ }^{2}$ It must be difficult for those who were not part of the policy discussions during the mid 1970's to understand the extent of disagreement as to what was taking place in the economy and disagreement as to the proper role of little used policy instruments such as across-the-board tariff reductions and exchange rate changes. It may seem inconceivable now but at that time the Australian Treasury opposed both an acrossthe board-tariff cut and a system of flexible exchange rates. It was firmly of the view that a fixed exchange rate was necessary to impose fiscal discipline on government. For a flavor of the debate surrounding tariff cuts, see Gruen (1975).

${ }^{3}$ At 1970 , manufacturing employment was 20 per cent of all employment. Today, that proportion is 9 per cent. Resource re-allocation effects will be greater this time because the mineral boom is larger, but since most of the manufacturing adjustment occurred during and after the last mineral boom, the resource shifts will be more dispersed across different sectors, more focused within the service sector and probably more evenly spread across full and part-time workers. These characteristics should make the resource reallocation adjustments less costly. The employment declines were accompanied by a rapid growth of the welfare state that has only recently been arrested. At the peak one in four Australians were receiving welfare payments for their personal income support.
} 
in Australia so these reflections will focus more on an issue which is less well understood and, to my mind, is the defining characteristic of the current boom at this time. ${ }^{4}$

This boom is different from that of the 1970's in one important respect. At this point, the mining boom is being driven, overwhelmingly, by export price changes and not export volume growth. The new analytical issue, therefore, revolves around whether it matters whether the mineral boom is being generated by price or volume changes? These reflections argue that, in many respects, it matters a great deal. Large increases in export prices raise a range of new analytical questions which give rise to exciting new research agendas. The prime issues we focus on are how to measure the increase in Australian living standards in response to the terms of trade increase and the relevance of this measurement for interpreting the changes that are occurring in the Australian economy.

These reflections are presented as follows. Part 2 sets the scene and documents the relative contributions of prices and volumes to the new mineral export boom. Part 3 discusses how to measure the mineral impact on Australian average living standards. Part 4 applies the measurement formula to Australian data. The mining impact on living standards is so large that in Part 5 the increase is placed in an international context and Australian outcomes compared with those of the US. The results of the comparison are spectacular and indicate that Australian average living standards now exceed those of the US. Part 6 explores in more detail the nature of these calculations, develops the analysis a little more and begins to map out new research agendas. Part 7 looks to the future and conjectures what might happen if export prices return to their long run trend values. Part 8 offers concluding comments.

\footnotetext{
${ }^{4}$ The mineral paper lead to wide ranging contributions by Australian economists including A. BlundellWignall and R. G. Gregory (1990), W. M. Corden (1984), P. J. Forsyth (Forsyth and Kay (1980), R. Maddock and I. McLean (1983), N. V. Long (1983), R. H. Snape (1977), A. Stoeckel (1979), P. Warr (2006) and E. Shann (1983). P. J. Forsyth's association with the Institute of Fiscal Studies was an important early channel for the ideas to travel to the UK. The IFS invited me to give presentations and introduce the mineral paper ideas to officials from the UK Treasury, Bank of England and to academics. Subsequently, Corden and Neary (1982) added to and more firmly established these ideas in the international academic literature. They adopted the term "Dutch Disease" from a Nov $26^{\text {th }} 1977$ Economist article rather than the colonial "Gregory Thesis", a term originally applied by the Australian newspaper and C. Hurford, the Member of Parliament from Adelaide, South Australia.
} 


\section{The Importance of Export Prices and Terms of Trade Increases}

In the Australian international trade model, pioneered by Wilson (1931) and Swan (1960) and developed further by Salter (1959), Corden (1960) and Gregory (1976), there are three goods; exports, imports and non-internationally traded home goods. This three good model becomes analytically powerful when the terms of trade are fixed and the model can be reduced to two goods and two prices, non-traded goods and traded goods (exports and imports can be aggregated together using their fixed price relativity, the terms of trade). The price ratio of traded to non-traded goods is referred to as the real exchange rate.

The mineral paper was firmly within this tradition and assumed fixed terms of trade. But the data indicate that a fixed terms of trade model is not sufficient today. Figure 1, for example, plots prices for two important mineral export groups - Basic Metals and Other Resources. Beginning from 2003, the price increases are extraordinary and of the order of 250 to 350 per cent.

The large price increase, for a significant share of exports, converts into large terms of trade changes. It is noticeable from Figure 2 that the Australian terms of trade always improve during world economic booms - 1972-73, 1988-89 - but the increases are relatively short lived and last less than three years. This mineral boom is quite different. The terms of trade upswing is three times larger than any upswing over the last fifty years, the increase is longer lasting - the period from trough to peak has extended over a decade - and the terms of trade have remained high even though the developed world is in recession.

Such large and sudden shifts in the terms of trade, and such persistence at high levels, suggests that the analytical emphasis should be placed on export price changes and not increases in export volumes. A fixed terms of trade model applied to the current mining boom is clearly inadequate. To emphasize this point, Figure 3 plots the total export/GDP volume ratio set at unity in 1959. These data show a constancy of the export/GDP share during the 1970's, a fairly strong increase during the 1980's and early 
1990's and then, somewhat surprisingly, near constancy in this ratio for the last two decades. The other noticeable feature of Figure 3, which we will discuss further, is the rapid rise in import volumes as a share of GDP. Since the terms of trade began to increase from 2003 the import/GDP volume ratio increased 50 per cent and the export/GDP volume ratio fell marginally. To this point, export price increases have had their largest impact on import volumes and little impact on export volumes. There is no mining export boom of sufficient magnitude to change the total export/GDP volume ratio.

\section{3}

\section{Measurement Mechanics: The Income Effect of Terms of Trade Increases}

It has been well known among Australian policy analysts, at least since the Korean War boom, that large increases in the terms of trade can generate large real income gains. ${ }^{5}$ What is not well known is how to measure real income changes in response to terms of trade changes (direct effects) and how these direct income effects relate to changes in real income from RGDP responses (the indirect effects). Indeed, these are not straightforward tasks and there is no universal agreement on how to proceed (see Silver and Mahdavy (1989), UN (2008)).

The key analytical issue arises as follows. Most macro growth analysis relies on real gross domestic product (RGDP) as a measure of real income. But RGDP, is not a complete measure of real income gains when there are large increases in the terms of trade. RGDP attempts to measure volume increases in goods and services and, by construction, does not attempt to measure any real income changes that arise directly from the price of imports and exports. Hence, the usefulness of RGDP as a measure of income and living standards during a mineral boom will depend on whether the

\footnotetext{
${ }^{5}$ The very large, but temporary increases in the Australian terms of trade in response to the Korean War boom, and the associated large increase in national income, helped to provide impetus to the development of the Australian international trade model based on the traded non-traded goods dichotomy - Salter (1959), Swan (1960) and Gregory (1976). But surprisingly, these models invariably assume fixed terms of trade when the Korean War boom was an export price and terms of trade change phenomenon. It should also be noted that the major income loss from the depression of the 1930's was from the terms of trade fall rather than from an output loss, Gregory (1988).
} 
additional income from the mineral boom is being generated by an increase in export volumes, measured by RGDP, or an increase in export prices, not measured by RGDP.

The inadequacy of RGDP can be illustrated by the flowing example. Suppose export prices double but all other prices and real outputs in the economy are unchanged. In this example, current price GDP increases only because export prices increase. To measure RGDP national account statisticians deflate each component of current price GDP by its own price deflator to calculate the underlying volume. When the higher export value is deflated by the higher export price this will indicate correctly that the export volume and RGDP have not changed. But, an export price increase, ceteris paribus, has increased real income. ${ }^{6}$ A country must be better off when export sales double in price.

How should this increase in real income, generated by an export price increase, be measured? The usual response can be simply illustrated as follows. ${ }^{7}$ Expenditure estimates of current price GDP can be written as

$$
G D P=D-M+X
$$

where $D$ is current price total domestic final expenditure, $M$ is the current price value of imports and $X$ is the current price value of exports. To produce an estimate of RGDP each item on the right hand side of (1) is divided by its own price deflator.

To account for the income effect flowing from a terms of trade change the usual response is to deflate $X$ and $M$ not by their price deflators but by a common price deflator that will reflect the extra expenditure opportunities (the income increase) brought about by the export price increase. Hence, a new concept real gross domestic income (RGDI) is defined as

$$
R G D I=R G D P-\left(X / P_{x}-M / P_{m}\right)+(X-M) / P^{*}
$$

The RGDI calculation therefore involves removing from RGDP the value of exports and imports, deflated by their own price deflators to calculate $x$ and $m$, the second term on the right hand side of (2) - and replacing them in the RGDP calculation by volume measures of exports and imports calculated by the application of a different deflator.

\footnotetext{
${ }^{6}$ When the terms of trade change, real GDP calculated by the income or expenditure path will no longer equal real GDP calculated from the production path.

${ }^{7}$ The precise definition applied by the ABS can be found at ABS (2004).
} 
The difference between these two sets of import and export "volume" measures, the second and third term of (2), is referred to as a "trading gain" which can be written as

$$
x\left(P_{x} / P^{*}-1\right)-m\left(P_{m} / P^{*}-1\right)
$$

Where $x$ and $m$ are export and import volumes, calculated by application of their own deflators. Trading gains arise therefore from relative price changes among exports, imports, and the price deflator $P^{*}$ and the weights provided by export and import volumes calculated from their own deflators. If there is no change in any of these price relativities, between one period and the next, there is no price generated trading gain in that period. Under these circumstances, the change in RGDI is equal to the change in RGDP.

What deflator $P^{*}$ should be chosen to measure the trading gain? There is no universally accepted answer to this question, although it has been posed for almost a century (Taussig (1927), Dorrance (1948-1949), Nicholson (1960), Silver and Mahdavy (1989), Diewert and Morrison (1986), UN (1968) and UN (2008). Perhaps the reason for the lack of an accepted answer is that there is no correct response? While it seems straightforward that the extra export revenue generated by higher export prices should be deflated by the price index of the use to which the extra revenue will be put there is no way of knowing exactly what this use might be or when it might occur. So the only thing to do is to make a reasonable assumption and proceed on this basis. There are two potential price deflators with wide support. ${ }^{8}$

Academics with an index number focus are increasingly recommending that $P^{*}$ be measured by the final domestic expenditure deflator. They argue that domestic expenditure (consumption) is the purpose of economic activity and the right living standard measure. They also argue that this deflator better captures all relative price shifts that are occurring in the economy (Diewert and Morrison (1986), Kohli (2004),

\footnotetext{
${ }^{8}$ As might be expected, official statisticians have been uncomfortable with a concept as amorphous as RGDI. But, even so, it is difficult to comprehend how controversial RGDI and the choice of deflator have been. The UN in their publication, The System of National Accounts (UN 1968, 1978), recommended that a terms of trade adjustment not be included in official statistical publications (Silver and Mahdavy 1989). But the UN has been slowly changing its position and the 2008 SNA publication suggests that the official statistical bureaus should account for terms of trade changes but offers no single recommendation as to how this should be done (see Kohli (2004), ABS (2001), SNA (2008), Silver and Mahdavy (1989)).
} 
Macdonald (2010), Reinsdorf (2010), Feenstra, Heston, Timmer and Deng (2009)). This deflator opens up many avenues for analysis - the role of each the three price deflators, $P_{x}, P_{m}$ and $P^{*}$, and the role of the export and import weights. But with this analytical richness comes complexity. For example, even if the terms of trade do not change there may still be trading gains if $P^{*}$ changes at a different rate than export and import prices. When this occurs the trading gain is labeled a real exchange rate change - a gain from a change in the price of traded to non-traded goods. This concept is central to the fixed terms of trade models of Swan (1960), Salter (1959) and Gregory (1976).

Official statistical agencies ${ }^{9}$, however, usually adopt a simpler approach and choose the import price deflator which, upon substitution into equation (3), simplifies the trading gains to

$$
x\left(P_{x} / P_{m}-1\right)
$$

This calculation effectively adopts an import volume metric for the trading gains. and implies a narrower definition of trading gains which can now only arise from terms of trade changes. There is no role for the price of non-traded goods.

One argument underpinning the choice of $P_{m}$ as a deflator is that from a nation's viewpoint the purpose of exports is to provide foreign currency to buy imports, hence the use of an import metric (Nicholson (1960). Furthermore, if the economy is operating at full capacity, and keeping export production fixed, additional imports is the only margin available for increased resources in the short run. Other advantages are that the terms of trade enter into the calculation in a simple way and the formula is easy to intuit.

In subsequent empirical analysis, we choose the import price deflator as $P^{*}$ primarily because this is the deflator which underlies the official RGDI series published by the ABS. Also, over the period of interest, the estimated Australian trading gains do not differ significantly when calculated with either of the two main deflators.

The adoption of the import price deflator enables equation (2) to be written as

$$
R G D I=R G D P+x\left[P_{x} / P_{m}-1\right]
$$

where RGDI is the sum of two terms RGDP and the trading gain.

\footnotetext{
${ }^{9}$ The UK, US, Canada and Australia adopt the import price deflator when calculating RGDI.
} 
Since RGDI and the trading gain concepts are not that well known, it is worth spending a little time exploring these concepts when $P_{m}$ is chosen as the deflator (see also Coleman (2008).

First, RGDI consists of two parts; a volume measure, RGDP, and a price measure, the trading gain. A terms of trade improvement must produce a trading gain for the nation (the direct price effect). There may or may not be a volume effect depending on how RGDP responds to the terms of trade changes (the indirect effect). A large increase in export prices would normally produce a direct and indirect effect both of which would normally be positive.

Second, no matter how RGDP responds (the indirect effect), it cannot change the trading gain (the direct effect) as long as the price of exports and imports are exogenously determined on world markets. The Australian response to a terms of trade change is very unlikely to affect the world price of imports (Australia is a small country) but for exports this assumption may not be strictly correct because for many key commodity exports Australia is a relatively large supplier. For this paper, however, we assume no feedback between Australian RGDP responses and the terms of trade. ${ }^{10}$

Third, it follows from the above assumption that the direct trading gain effect can be thought of as a free gift in that it requires no additional resources to produce the gift and the gift cannot be eroded by Australian RGDP changes unless they affect world prices.

Fourth, although a terms of trade change will affect the Australian nominal exchange rate, and has done so in this and the previous mining boom, a change in the nominal Australian exchange rate should not normally affect the terms of trade and

\footnotetext{
${ }^{10}$ The RGDP response may affect the trading gain if RGDP affects world prices. The nature of this link is complex and will vary with the time horizon. An RGDP change may also increase in the export volume weight attached to the trading gain and affect the trading gain via this route. In the short run both these effects can be safely put aside since they will be small.
} 
therefore should not affect the trading gain. ${ }^{11}$ The exchange rate change will probably affect RGDP (the indirect effect). of the terms of trade change. ${ }^{12}$

Fifth, a change in import prices will affect trading gains but a change in import volumes will not. The pattern or volume of imports do not enter the trading gain formula. There is also no account of whether there is a domestic industry producing close substitutes for imports or whether the value of imports is greater or smaller than the value of exports. ${ }^{13}$ Hence, there is no direct mapping from trading gains to structural changes or resource re-allocation across sectors. Any import effects must work though the RGDP component of RGDI.

Sixth, an import or export price change has a symmetrical effect on trading gains. But it does not follow, in the short run, that the effect on the economy is the same irrespective of the source of the terms of trade change. The links between export and import prices and resource allocation in the home economy will work through the RGDP component of RGDI.

Seventh, the trading gain formula takes no account of foreign capital ownership or the degree to which the export sector uses Australian or non-Australian factors of production. In principle, RGDI can be adjusted to account for foreign ownership but we put this issue aside. ${ }^{14}$ To account for foreign ownership requires a third term to be added to the RGDI calculation (5) to subtract the share of the trading gain that accrues to foreigners. The relationship between terms of trade changes, foreign ownership of mining

\footnotetext{
${ }^{11}$ We have, by and large, put aside a discussion of exchange rate changes but the association between Australian mining booms and the exchange rate is very strong (Blundell-Wignall and Gregory (1990)). Between Sep 2001 and June 2011 the Australian exchange rate has appreciated 218 per cent against the US dollar, 176 per cent against SDR's and 165 per cent against a trade weighted index.

${ }^{12}$ For exchange rate changes to affect the terms of trade requires different exchange rate pass through relationships among exports and imports or a different pattern of currency sourcing exports and imports across countries so that country specific exchange rate may affect the terms of trade through composition effects. It is unlikely that either of these preconditions matter sufficiently for exchange rates to significantly affect the domestic price ratio of exports and imports (see ABS 2004).

${ }^{13}$ The United Nations has suggested that when the value of imports exceeds exports the price deflator chosen could be the export price deflator. Under these circumstances, when the terms of trade change, the import volume will affect the trading gain.

${ }^{14}$ Real net national disposable income (RNNDI) goes beyond RGDI and takes account of depreciation of fixed capital and dividends and interest payments to and from the rest of the world. The ABS (2004) comments on movements of these two measures and states that "differences between RGDI and RNNDI are generally small." Nevertheless, the issue requires further examination.
} 
output and the impact on the Australian economy and living standards is a grossly under researched area. Export price increases which largely accrue to foreign capital - the two largest export mining companies in Australia are foreign owned - will have a different impact on Australian living standards than if they accrued to Australian capital.

Eighth, the terms of trade may not change (there are no trading gains) but if import and export prices change, relative to domestic prices, there may still be very large impacts on resource flows within the economy. These effects will be included in RGDP. When a different trading gain deflator is used an additional term is added to RGDI to measure real exchange rate changes (Macdonald 2010).

\section{Terms of Trade and Australian Income Growth Per Capita}

How much has Australian income increased in response to the exceptional lift in the terms of trade? There are two important short run gains.

First, there is direct trading gain income which is measured by the income gap between RGDP and RGDI. Apart from issues surrounding the choice of deflator, measuring this direct income effect is quite straightforward.

Second, trading gains produce an indirect income effect as increased optimism about future mineral prices will usually generate an investment boom that adds to RGDP which in turn, pari passu, adds to RGDI. Of course, this indirect income effect is only one contributor to RGDP and, because of this, there can be no universal agreement as to the exact contribution of the terms of trade through the indirect RGDP effect. ${ }^{15}$ Nevertheless, it seems clear that this indirect effect has been important. In response to the Global Financial crisis almost all developed economies are experiencing depressed RGDP growth rates and record high unemployment. Australia, in contrast, has avoided any significant falls in RGDP and is experiencing falling unemployment rates that are currently around 4.9 per cent and are considerably lower than the average over the last forty years.

\footnotetext{
${ }^{15}$ There has been some dispute as to the relative contribution of the stimulus package, the mining boom and general stability of the banking system to the stronger performance of the Australian economy since 2008. In addition at mid 2011 there is concern that the exchange rate effect of the mining boom along with high interest rates are depressing RGDP growth.
} 
An empirical estimate of the indirect effect involves a comparison between actual RGDP and a counterfactual, an estimate of what RGDP would have been without the trading gain. To estimate a counterfactual is a large and complex task which we do not attempt. Instead, in this instance, we adopt a descriptive and judgmental approach and turn to accounting identities to describe different sources of income growth and to provide an indication of how large the total gains might be.

Since we are interested in living standards of all Australians, RGDI will be expressed in per capita terms and related to direct and indirect trading gain effects by the following identity,

$$
\frac{R G D I}{P o p}=\frac{R G D P}{P o p} \times \frac{R G D I}{R G D P}
$$

The first term on the right hand side of (6) is $R G D P$ divided by the population. This measures living standards without adjustment for direct trading gain effects. The application of the second term, $R G D I / R G D P$, adjusts for the direct income effect of the trading gain. Figure 4 plots the change of living standards, and the accounting contribution of the first and second term, over the last fifty years (ABS 2011). We divide the discussion of the period into two, the long period 1960 to 2003 and the recent period beginning 2003 .

Over the long period, $R G D P / P o p$ has increased fairly steadily although there are noticeable downturns during the recessions of the early 1980's and 1990's but only a short pause in the growth rate during the 2001 recession. Living standards measured by $R G D P / P o p$ have increased about three fold over the past forty years.

The direct income effect of trading gains - RGDI/RGDP - is measured by the gap between RGDP and RGDI and contributed positively to living standards over the long period. There is a trading gain contribution in the early 1970's which has more or less stayed in place. But, the most striking feature of the long period is that the direct income effect of trading gains is of little practical significance. Over the long period, trading gains have lifted living standards by about ten percent of the total increase.

Since trading gains have not been very important over the long period, it follows that virtually all living standard growth, over this period, can be attributed to increased inputs and their efficiency in use to produce RGDP. It also follows, over this long period, 
that $R G D P / P o p$ is an adequate national accounts measure of changing living standards although, on average, there is a small understatement reflecting the small positive effect of the trading gains.

Recent history since 2003, however, is quite different in two important ways. First, over this short period, the direct income effects from trading gains have been large and persistent. RGDI has moved 13 percent above RGDP. This is an exceptionally large increase in income over eight years, accounting for 60 per cent of the per capita income growth. This substantial amount - the direct income increase from the trading gain - is equivalent to about $\$ 8000$ per person per year (2011 prices).

Second, it is noticeable that production per capita has not fallen during the current world economic recession, as it did in previous world recessions, but the growth rate has slowed. We can learn a little more about this slowing by decomposing RGDI per capita into

$$
\frac{R G D P}{P o p}=\frac{R G D P}{E m p} * \frac{E m p}{P o p}
$$

the product of labour productivity, (an index of production per employed person) and the proportion of the population employed.

When RGDP per employed person is added to Figure 4 the changes in RGDI per capita can be divided into the three elements; changes in trading gain income, labour productivity and the proportion of the population employed. Each of the series included is presented as an index number based at one hundred in Sept 1959.

Over most of the four decades since Sept 1959 the path of each series RGDI/Pop, RGDP/Pop and RGDP/Emp was similar, although the gaps between them widen towards the end. The relatively narrow gap between RGDP/Emp and RGDI/Pop which includes the trading gains and the changing employment-population ratio indicates that the driving force for living standard increases, over most of this period, were productivity gains, that is increased real output per employed person.

Over the last decade, however, and certainly since the mining boom began, circumstances have changed as the gap between RGDP/Pop and RGDP/Emp has opened 
a great deal and $R G D P / E m p$ has not increased substantially indicating that recent change in labour productivity have not been the driving force in living standard increases. The driving forces have been the factors which have increased the spread between RGDI/Pop and $R G D P / E m p$ - trading gains and rising employment-population ratios.

To illustrate this point the increase in living standards per capita since 2003 has been 24 per cent, an exceptionally high growth. Fifty-five per cent of this increase has been the result of trading gains. Thirty per cent has been the result of increased employment among the population. Only fifteen per cent has been the result of labour productivity growth. The growth of labour productivity, has slowed considerably and it has been the least important of the three contributors to living standard growth. Of course, equation (7) is an accounting identity, but it makes clear that over the mining boom period it is towards the increasing employment-population ratio and the trading gains to which we must turn to understand the positive factors contributing to living standard increases rather than towards labor productivity increases.

Finally, much of the commentary on Australian macro economic performance over the last decade has been directed towards the slowdown in labour productivity growth. Given the size of this productivity slowdown, and its recent trivial contribution to living standard growth, the commentary seems appropriate but, at the same time, it has not focused on the large positive contribution from trading gains and increased employment and, in that sense, the commentary has missed the main game.

Indirect trading gain income effects have clearly contributed to Australia avoiding the current recession among developed economies and presumably have been one reason for the employment-population increases. Indirect effects may be substantial and when added to the 12 per cent direct trading income gains the living standard increase effected by the mineral boom could be very large indeed. How large might the total income gains be? To help answer this question we need to explore counterfactuals 


\section{5 \\ Australia US comparison}

Since Australia has gained twice from the terms of trade increase - experienced a substantial increase in trading gains and avoided the economic downturn in RGDP - the question is naturally raised as to how much has Australian income per capita caught up, or pulled ahead, of other nations? Recent experience of countries that have not been advantaged by terms of trade gains, and whose living standards changed over the last forty years, in much the same way as Australia, might serve as a counterfactual to estimate the path of Australian incomes in the absence of the trading gains.

In this respect, the US might be a good choice as per capita income usually grows at similar rates to Australia and the US has not been subject to noticeable terms of trade changes (Reinsdorf, 2010). The US has another advantage in that it is often used to provide estimates of the RGDP per capita that might be possible if the Australian economy were more efficient. ${ }^{16}$ The evolution of Australian-US living standards can be described by identities (6) and (7), defining each element as Australian outcomes relative to those of the US.

The Australian-US comparisons are quite revealing. ${ }^{17}$ Consider RGDP per capita (Figure 5). Until 2003, there has been remarkable stability in this relativity. Australian

\footnotetext{
${ }^{16}$ This comparison was motivated by the following considerations; (i) Australia has gained from a terms of trade improvement and the US has not (ii) the US has experienced the full force of the global financial crisis and Australia has not (iii) assessments of Australian economic growth performance usually focus on GDP levels and growth rates and often use US outcomes as the counterfactual "efficient" production frontier (Gregory (1993), Quiggin and Dowrick (1997), Rahman (2005), Davis and Rahman (2006) and Battersby (2006).

${ }^{17}$ The series used for the comparison are from The Conference Board which has put together macro data from the World Bank, IMF, OECD, Eurostat and national statistical agencies. The series are real GDP per person in current US EKS dollars. The Conference Board takes the Purchasing Power Parity benchmarks between the US and Australia in 2005 and adjusts this index through time by the GDP deflators in each country. This produces a PPP for each year which can be applied to nominal GDP data for each country. The use of GDP deflators means that real GDP measures do not include any terms of trade effects. Notice that the exchange rate plays no role in these calculations.

There are two PPP adjusted GDP data series available "Geary-Khamis" (1990 US dollars) and the "EKS" (2005 US dollars). There is a different level effect between the series but no differences in trends or cycles. Before the large Australian terms of trade change the average "GK" Australian GDP per capita is about 77 per cent of that of the US. The "EKS" average ratio is near 88 per cent. We adopt the OECD preferred "EKS" series which is based on later data. For a full data description see Chen, Gupta, Therrien, Lervanon and Bart van Ark (2010)
} 
RGDP per capita hovered between 86 and 93 per cent of US levels for forty years. Despite different economic policies in each country, different immigration experiences, different labour force participation patterns and the 1970's Australian mineral boom there was little variation in relative RGDP per capita until 2003.

Since 2003, however, Australia has been catching up and RGDP per capita, PPP adjusted, is now about 97 per cent of US levels. Something has changed over the last eight years, something which has not been achieved in the previous forty years. The association of the current mining boom with the sudden lift in RGDP per capita in Australia, relative to the US, suggests that indirect trading gain income effects may be large.

What is the source of this sudden catch-up in RGDP? Does it arise from increased Australian efficiency of resource use, which we measure as relative RGDP per employed person, or does it arise from a higher employment utilization of the population, E/P? We can begin to answer these questions by using identity (7) to decompose RGDP per capita of each country into these two elements. Their contribution is most easily seen if each is expressed as an index number with the 1959 base set at unity (Figure 6).

The decomposition reveals a changing pattern over time which is quite different during the two mining booms (Figure 4). Over the 1960's, the US exhibited higher labour productivity and slightly lower employment-population ratios and their interaction produced a higher US-RGDP per capita. In this period, labour productivity and employment-population ratios grew at similar rates in both countries and relative RGDP per capita did not change significantly.

These relationships were substantially disturbed by the macro experiences and mining boom of the early to mid 1970s. ${ }^{18}$ Australian labour productivity increased substantially, relative to the US, and remained at these new relative levels for the next three decades. At the same time, the employment-population ratio across the two countries followed a path which was the mirror image of the relative labour productivity

\footnotetext{
${ }^{18}$ In Australia, the 1970's mineral boom was associated with high inflation, substantial real wage increases and expansion of new welfare programs (Gruen, (2006), Gregory and Frijters (2006) and Gregory (1993)). The US also experienced substantial changes, high inflation and the emergence of skill biased technical change. Both countries experienced very large increases in unemployment to record post World War 2 levels.
} 
ratio, increasing substantially in the US but remaining constant in Australia as an increasing proportion of the Australian labour force entered the expanded welfare programs. The mirror image reflections of labour productivity and employmentpopulation changes meant that relative RGDP per capita continued to be largely unchanged.

From the middle to late 1990's there is another shift in outcomes as labour productivity and employment-population ratios begin to revert back to their cross country relativities of two decades earlier. In relative terms, labour productivity begins to fall in Australia and the employment-population ratio begins to rise. Again, each series is largely a mirror image of the other, so the RGDP per capita ratio remains largely unchanged.

Finally, beginning 2003, when significant trading gains begin to occur in Australia, the growth patterns continue but the Australian relative employmentpopulation ratio increases begin to dominate the Australian relative labour productivity declines and Australian RGDP per capita begins to catch-up with the US. This history suggests two important points which are not widely known.

First, RGDP per capita has not been closely related to the changing relative efficiency of labour utilization across the two economies. For most of the period, a strong mirror image effect has operated;- any increase in relative labour productivity was offset by a decrease in the relative employment-population ratio. Long run stability of the Australian/US RGDP per capita ratio, until recently, is an important fact to be explained. Why has Australia, until recently failed to catch-up to the US?

Second, the decomposition makes clear a major difference between the two mining boom periods - the first boom is associated with large relative employmentpopulation loss in Australia and the second with a substantial gain. Over the last decade, the Australian employment-population ratio has increased 8 percent and that of the US has fallen 6 percent to produce an Australian employment-population ratio that is now 12 per cent above the US (Figure 7). The Australian employment-population ratio has risen 
to its highest level ever. That of the US has fallen to the level prevailing twenty-five years ago. ${ }^{19}$

RGDP comparisons and decompositions, take no account of trading gains. ${ }^{20}$ When this is done the changes in the cross-country living standard comparisons are spectacular (Figure 5). Direct trading gain income effects add a further twelve percentage points to Australian living standards. Together, direct and indirect trading gain income effects have lifted Australian living standards, relative to the US, from a long run average of around 92 per cent, over the 1959-2003 period, to a current level of 115 per cent. In just eight years, Australian living standards have increased an amazing 25 per cent, relative to the US; an extra-ordinary change - about one third attributable to increased production of goods and services per capita and two thirds attributable to direct income effects from trading gains. The fifty year history of relative income stability across the two countries, before the terms of trade change, would have suggested that a move of Australian living standards to be above US levels was simply just not possible. ${ }^{21}$

Indeed, I doubt whether a change in relative living standards, of this magnitude and over such a short period, between Australia and other large developed economies has ever occurred before, outside of war periods and their aftermath, and certainly not since the mining boom of the nineteenth century. The special feature which makes this change in living standards so substantial is the positive interaction of two forces favourable to Australia, the trading gain and relatively higher growth of RGDP capita, brought about primarily by increasing employment levels and avoiding the current world recession. Usually, Australian trading gains are positively associated with strong economic growth in developed economies, including the US, and, in these circumstances, the Australian relative income increase is largely confined to the direct effect of the trading gain since

\footnotetext{
${ }^{19}$ There has been a small change in relative hours worked per person across the two countries which do not significantly change the conclusions based on employed persons.

${ }^{20}$ The relative unimportance of the US trading gains can be seen by comparing the US Department of Commerce Command GDP series 1959-2009 with that the unadjusted GDP series.

${ }^{21}$. There is inevitably uncertainty about relative income levels across countries and from this perspective PPP calculations require more attention and need to be updated. However, as noted earlier the choice of PPP index from the Conference Board has virtually no effect on changes in income relativities through time because PPP calculations have typically been made for one year and then for all other years the PPP calculation is adjusted by the relative rates of GDP price increases for each country.
} 
all countries share in strong RGDP growth. The dislocation of the close positive relationship between the Australian trading gain and the economic growth cycle of developed countries, is a completely new feature, generated by the decoupling of Asian growth rates - primarily China and India - from the growth rates of the developed economies. Relative to most other developed countries Australia has been twice blessed by the terms of trade increase.

The understandable failure of recent economic research to anticipate the extraordinary and unexpected lift in Australian living standards is worth noting. The most recent studies of Australian living standards, relative to the US, have focused on RGDP per capita, where the dominant fact to be explained, over the fifty years before 2003, is the relative constancy of the Australian-US relativity (Rahman (2005), Battersby (2006), J. Wilkie and T. McDonald (2008), OECD (2008)). The focus of these Treasury and OECD studies was primarily to explain why Australian living standards had failed to increase relative to the US for almost half a century and why in the future it might be expected that there would be very little or no catch-up. Perhaps the best that could be hoped for was that if good policies were pursued, Australian living standards may grow at the same rate as the US.

These studies estimate that about half of the living standard gap could be explained by the negative contribution of Australia's distance from world markets (an influence unlikely to be offset). Furthermore, the OECD estimated that the relative favorable advantage delivered by the Australian mineral sector offset only about 2.3 percentage points of the living standard gap with the US, a contribution about one fifth as important as the negative contribution of Australia's remoteness.

But, as is demonstrated above, the mining boom, primarily through a trading gain price effect may have increased Australia living standards by as much as 25 percentage points, relative to the US, a much different estimate from the OECD estimated mining volume contribution of 2.7 percentage points to narrow the gap. All these studies focus on RGDP, ignore trading gains and therefore provided an inadequate framework to understand the very large lift in living standards that has suddenly occurred. 


\section{Some Preliminary Reflections on Free Gifts and their Macro Implications}

Trading gains are produced by price changes and not by output changes. Hence, no additional resources are required to realize trading gain income. This special feature has two implications that are discussed in this section. First, because no additional resources are required, should trading gains be thought of as a free gift and, if so, what are the economic implications of this free gift for the macro economy? ${ }^{22}$ Second, because no additional resources are needed, the only way trading gains can impact on RGDP is through indirect effects generated by the increase in income. What is known about these indirect effects?

\subsection{The free gift?}

The trading gain is substantial. Over the last six or seven years it has averaged about 10 per cent income to be added to Australia's annual output of goods and services. This unusual situation prompts a range of questions which are yet to be fully explored. Is the gift truly free? Can it really be so large? Who receives this free gift? How does it impact on the economy? And, perhaps most importantly, what happens if the free gift is suddenly withdrawn?

These are large, complex, interrelated, open ended and largely ignored research questions which were not central to the 1976 analysis of resource allocation responses to a volume based mineral boom. Even today, during a period of large mineral price increases, trading gains and losses are not very important among most OECD countries, with the possible exception of Australia, Norway and Canada. It is not surprising, therefore, that trading gain effects on living standards are still not receiving adequate attention. The required research agenda is extensive and the following few pages reflect on some issues that this agenda should address.

\footnotetext{
${ }^{22}$ These remarks, of course, refer to a situation where the export price increase was not anticipated and did not lead to investments in earlier periods that are now just receiving their anticipated returns. Most mining investments over the previous two decades before 2003 occurred well before there was an indication of such a substantial increase in the price of mineral exports.
} 
Of course, if trading gains lead to substantial changes in production patterns these shifts will inevitably increase the costs associated with a faster rate of resource reallocation in the economy and in the short run these costs should be set against the free gift. Resource reallocation was discussed extensively in the context of the 1976 mineral paper and because of this it was decided to put aside for this paper. Despite possible adjustment costs we continue to use the term "free gift" because it emphasizes that this is an income source additional to RGDP.

\subsection{Who Receives the Free Gift?}

One difficulty encountered when attempting to answer this question is that the size of the free gift is an artificial construct. Its measurement only exists when an attempt is made to estimate income in real terms and obviously the real income estimate will depend on the deflator choice. No individual or company only sells export products and spends the revenue generated only on imports. Hence there can be no easily derived direct mapping from the trading gain to an individual or company. Hence, it is not possible to be precise as to the magnitude or the way in which the gift, measured by application of the import price deflator to the current value of exports, is delivered to various groups. Trading gains are quite different from RGDP estimates which, in principle, can be built up from individual or company outputs, income, expenditure and the prices received and paid. Nevertheless, some rough calculations can provide some feel for what is happening to trading gain income.

Trading gain income is delivered throughout the economy by the changes in relative prices brought about by the terms of trade shifts. In the first instance, a substantial part of trading gains, originating from mineral export price increases, flow to resources involved in the mining export industry which is very capital intensive and a very small employer of labour. Consequently, much of the initial free gift will flow directly into mining industry profits rather than the income of other factors or production. ${ }^{23}$ This is very evident in the national accounts. Table 1 , for example, presents current price mining industry profits and total employee compensation as a proportion of all industry equivalent aggregates. These ratios are stable until mineral export prices begin to increase and then there is a large increase in mining profits which, over the last 
four years, have doubled as a proportion of all industry profits, increasing from 7 to 14 per cent, a truly exceptional change. Mining profits in the Australian economy now account for one dollar of profits in every seven.

Total compensation of mining employees, as a ratio of all industry employee compensation is very low, around 2 per cent, and in percentage point terms this share has not changed significantly in response to the export price increase. Labour, therefore, has not received and cannot receive a significant share of the free gift through the change in the price of labour in mining relative to other industries. ${ }^{24}$

A rough calculation, based on Table 1, suggests that the doubling of mining profits, relative to profits of other industries, is equivalent to 3-4 per cent of current price national income, an estimate which is significantly less than the free gift which is estimated to be approximately twelve per cent? Who receives the remaining 60 to 70 per cent of the direct trading gain? What other relative prices change?

From the nation's perspective, direct trading gain income can only be delivered by changing resource flows to and from Australia. This will primarily occur through increased imports. ${ }^{25}$ It is in recognition of the link between the trading gain and the international resource transfer that the import price index was chosen as the relevant deflator of export values.

Trading gain income leads to increased imports by a change in the relative price of traded to non-traded goods and the change in consumption and production patterns that these price changes induce. The fall in the relative price of traded goods, usually effected in the short run by exchange rate changes, takes some of the initial trading gain income away from the mineral industry - by reducing export prices in domestic currency - and re-allocates the trading gains to those who buy imports or products with a large import component - which are now cheaper in domestic currency than they otherwise would

\footnotetext{
${ }^{24}$ Finally, Table 1 makes clear that mining industry value added in current prices has doubled as a proportion of the value added of all industry, but, in constant prices, mining value added has not changed as a proportion of industry value added. Hence, to this point, the free gift has not led to noticeable changes in real mining output, or a significant increase in utilization of resources in the mining industry. That is yet to come. The main direct contribution to RGDP to this point flows from the construction industry that is building new mining facilities and mines.

25 Trading gain income may also be made effective by setting free resources from export production to be available for domestic use, or by changing net wealth holdings with the rest of the world.
} 
have been. The majority share of trading gains, therefore, are likely to be delivered by changes in relative prices through an appreciation of the real exchange rate which leaves the terms of trade unaffected - and hence the size of the gift - but reduces both export and import prices relative to domestic prices. Since mining employs about 2 per cent of the labour force, labour will primarily receive its share of trading gain income through greater purchasing power generated by lower import prices.

Since trading gain income is large it is to be expected that the change in relative prices will also be large. Figure 8 presents three important price ratios to indicate the large changes in relative price shifts that are occurring. The price ratios are the Household Final Consumption deflator divided by the price deflator of GDP, exports and imports. The recent extra-ordinary change in these relative prices is clearly evident.

First, after increasing steadily over the 1979 to 2000 period the path of the final household consumption - export deflator ratio suddenly changes direction in response to the large increase in export prices and falls about 30 per cent, the largest fall over this fifty year period.

Second, there is a noticeable trend change in the household consumption- import price ratio as it begins to increase at a faster pace from the beginning of the last decade as imports fall in relative price terms.

Third, there has been a recent 11 per cent fall in the final household consumption deflator relative to the GDP deflator.

These large relative price changes raise two important points that should be noted. One point is that the sudden trend reversal and large increase in export prices has tended to overshadow how important falling import prices, relative to domestic prices, have been in both generating and redistributing trading gains. Falling relative import prices seems to be an increasingly significant feature of the Australian economy.

Another point is that although the terms of trade are independent of exchange rate changes the ratio of traded and non-traded relative prices are not. Hence, some of the recent import price falls, relative to the household final consumption deflator are generated by the export price effect on the exchange rate. Indeed, as was noted earlier, to this point it has been the import/GDP ratio in volume terms that has adjusted to the terms of trade increase rather than the export/GDP volume ratio. 
Establishing the impact of changing relative prices on the distribution of trading gain income is a complex task and I look forward to this research agenda being developed. The task of constructing price indices for various groups in the economy is becoming increasingly important and the task of establishing a counterfactual path for relative prices is becoming increasingly onerous (Feenstra, Mandel, Reinsdorf and Slaughter (2009).

\section{7}

\section{What if the free gift is taken away?}

In the past, large Australian trading gains have tended to be short lived. Are circumstances different now? Will there the lift in Australia's living standards be permanent?

It is not possible to confidently predict the future terms of trade path as is evident from the surprising fact that industry and policy experts did not foresee the large, rapid and sustained export price increase that began around 2003 (Treasury, 2002-2003) ${ }^{26}$. The current consensus, however, is that the terms of trade will not fall back to previous levels, although in the past they have always done so and fallen beyond the previous low point. ${ }^{27}$ But what if the terms of trade did fall? How far could Australian living standards decline and what would be the nature of the adjustments that would occur?

The direct living standard loss, measured by a trading gain loss, is a straightforward calculation. If the terms of trade moved back to their 2003 ratio, RGDI,

\footnotetext{
${ }^{26}$ In the year that the terms of trade began to increase to their highest level ever in the post war period, generated by mineral price increases, the Treasury commented in Statement Number 4 of the Budget Papers that,

"The terms of trade is likely to be more stable in the future because of the diversification of Australia's trade baskets (across products and destinations), the improved insulation of the Australian economy from foreign economic events, and the generally more stable global economy. The increasing importance of ICT and other related products in Australia's imports basket is likely to provide continued strength to the level of Australia's terms of trade." Treasury (2002-03), (My italics).

They, along with many others were focusing on import price changes and increased export diversification and completely missed the coming export mineral price boom.

${ }^{27}$ The Treasury in the 2010 Intergenerational Report assumes that the terms of trade will remain above the previous 1974-75 peak for the next twenty years but will steadily decline to be about thirty per cent above the 1980-2000 average. These projections therefore assume that Australian living standards are likely to remain above those of the US for some time unless US RGDP per capita begins to reverse its recent deterioration relative to Australia.
} 
without any indirect RGDP response, would fall 12 per cent. An RGDI fall of this magnitude would be the largest negative macro shock to Australian living standards since the 1930's depression (Gregory, 1988). ${ }^{28}$

During recent recessions, 1981-84 and 1990-1993, RGDI falls were temporary and much smaller than 12 per cent and yet they produced considerable and long lasting increases in unemployment. In the early 1980's recession, for example, RGDI fell 7 per cent between June 1982 and March 1983 and then increased rapidly to reach a new peak within five quarters. Unemployment, however, increased from 6.8 to 10.3 per cent over a similar period and remained high for many years. In the early 1990's recession, RGDI fell 3 per cent between June 1990 and Dec 1991 and then increased quickly to reach a new peak in four quarters. Once again unemployment increased to around 10 per cent.

Since the living standard fall from the removal of the trading gain would be two to four times the RGDI declines during the 1982 and 1991 recessions, and would be long lasting, could unemployment increase two, four or more times than that of previous recessions?

Furthermore, if RGDP responds to the fall in RGDI, as might be expected, the decline in living standards will be even greater. For example, if the RGDP/RGDI elasticity were unity - a twelve per cent drop in living standards, generated by a loss in trading gain income, produces a twelve per cent fall in production of domestic goods and services - then Australia would be subject to a twenty-four per cent reduction of living standards, a decline that is three to eight times greater than the fall in the 1981 and 1990's recessions. Would a 24 percent decline in living standards produce a seven to eight fold increase in unemployment to levels in excess of 30 per cent?

These calculations might seem to be alarmist but they illustrate a number of interesting and important points.

One point is that a real income loss from removal of a twelve per cent trading gain, and assuming a RGDP-RGDI elasticity of unity, produces a living standard loss that is very similar to the last decade loss in US living standards relative to Australia. So the mechanical calculation of changing living standards over time might seem about right. So

\footnotetext{
${ }^{28}$ Of course, if the terms of trade were to fall to the level predicted on the basis of long run trends, the fall would be even greater.
} 
why do I not believe that a 24 per cent reduction in living standards would increase Australian unemployment to three to eight times that of the 1981 and 1991 recessions? Is it because a dollar loss of living standards from the loss of trading gains is quite different from a dollar loss of living standards from a RGDP loss? It must be related to this, in part, because relative unemployment between Australia and the US only changed by about five to six percentage points and not 24 percentage points.

There are many slippage points in the link between changes in living standards and changes in labour market outcomes as measured by employment and unemployment. These slippage points can be summarized by a number of key parameters that need to be better understood.

First, employment outcomes relate to RGDP and not to the direct trading gains. So the first parameter of interest is how RGDP responds to trading gain losses. If the real production of goods and services is unaffected by removal of the trading gain then presumably nothing happens to employment through this link even though living standards are significantly affected. All the loss of trading gain income falls on imports. But this seems an extremely unlikely event, RGDP should fall and reduce employment and contribute further to the reduction of living standards so the elasticity should not be zero.

So what might be a reasonable guess as to the RGDP elasticity to a trading gain loss? How might this elasticity change over time? There have been very few attempts to answer these important questions, partly because Australia has not found itself in this situation since the Korean War. But there are some indirect estimates that can be found.

First, in an appendix to an OECD paper, Turner (2006) uses 2006 simulations of the Treasury TRYM model to measure the effect of a terms of trade increase. ${ }^{29}$ These simulations suggest, in the first year, that RGDP falls in response to the living standard increase, the fall being generated by resource reallocation across industry in response to the exchange rate appreciation. From the second year RGDP begins to increase, the elasticity is about 0.15 per cent, and from the third year forward the elasticity remains at

\footnotetext{
${ }^{29}$ Although the model had been fitted to data before the recent large terms of trade changes the output simulations can be used to provide some idea of the relevant elasticity. The simulations are for a 7 per cent increase in the terms of trade from an increase in export prices. This is equivalent to a 1.4 per cent trading gain. We assume symmetry and linearity of the response.
} 
about 0.4 per cent. An elasticity of 0.4 per cent suggests that a trading gain loss of 12 per cent would produce a RGDP loss of about five percentage points, this would produce a marginally greater RGDP loss than that of the recessions of the early eighties and nineties although, in this instance, it would be a permanent rather than a cyclical loss. ${ }^{30}$ The permanent loss must have very adverse effects on unemployment as in the previous recessions the loss of living standards only lasted four or five quarters.

Is 0.4 per cent a reasonable estimate for this elasticity? I don't know. It depends, in part, on the time period. Living standard variations generated by trading gain variations are made effective through import variations. So, in the long run, the trading gain RGDP elasticity could be very low as imports rise or fall to deliver the trading gain contribution to changing living standards in response to real exchange rate variations. In this short run, however, the RGDI-RGDP elasticity might be higher because of the investment response.

Second, there may well be a link between changes in trading gains and changes in labour productivity although the nature of this link is not clear. The sketchy empirical evidence seems to suggest, somewhat surprisingly, that trading gain income may reduce productivity both in the mining industry and at the macro economy level (Macdonald, 2010)..$^{31}$

Third, there is another link between depressed labour demand and withdrawal from the labour force which acts to mute the unemployment increase when trading gains are withdrawn. Since, 2003 relative employment between the US and Australia has fallen - percent but sixty per cent of this fall has been reflected in relative labour force participation rate changes rather than relative unemployment.

To conclude, very little is known about the interrelationships between variations in living standards, RGDI, RGDP, employment and unemployment. Given our extensive ignorance the simple empirical exercise of adopting a US counterfactual is probably the

\footnotetext{
${ }^{31}$ At the macro level, Macdonald (2010) remarks that the four countries with the largest increase in trading gains have all experienced relative productivity declines but offers no explanation as to whether this association is causal. At the micro level, the ABS (2010) and Topp, Soames, Parham and Bloch (2008) have recently provided productivity estimates that show, between 1974-75 and 2007-08, that multi-factor productivity has fallen in mining by 25 per cent and therefore, over this thirty year period, mining has been the only industry that has reduced Australian living standards by productivity falls..
} 
best that can be done at this point. But the need for more research, essentially with an econometric economy-wide model framework, is essential.

\subsection{Why don't Australians Feel Richer?}

Given the extraordinary large increase in per capita income since 2003, relative to the US and other high income countries, why do many Australians not feel that their living standards have made a discrete jump to another higher level?

One possible answer is that although Australian living standards have increased dramatically, relative to the US, they have not increased substantially relative to expectations formed by projecting past growth rates. The large increase in living standards from trading gains and a higher employment-population ratio has, more or less, replaced the loss of income from a below average growth of RGDP per employed person over the last decade (Figure 4).

Another possible answer, which raises a host of complicated issues which we cannot pursue here, relates to foreign ownership of mining resources. If the mining sector was completely foreign owned, then, virtually all the trading gain income, equivalent to 10-12 per cent of Australian RGDP, would go to foreigners except for Australian tax receipts. Furthermore, in the short run, accelerated depreciation and generous investment allowances for the mining industry may even remove most of these tax gains. Under these circumstances, the mining industry would operate as a foreign enclave and the gains to Australian living standards would be delivered only through indirect terms of trade effects that lead to RGDP being higher than otherwise, an outcome that may only occur during the building boom and not during the post construction period when the extra exports, which will make few demands on Australian resources, are produced.

Of course, the mining industry is not completely foreign owned but it is surprising, where foreign ownership of the two largest mining companies exceed 50 per cent that the relationship between trading gains and foreign ownership has not received more attention. ${ }^{32}$ Of course, if the terms of trade fall, and trading gains are lost, then foreign income falls along with that of Australians.

\footnotetext{
${ }^{32}$ When mining companies are primarily foreign owned there will be all sorts of timing effects impacting on the terms of trade - exchange rate relationship as foreign capital inflows increase at the beginning of the period, when the terms of trade increase, and dividend outflows are delayed to the end of the period when the quantity of exports increase and the investment phase has been completed.
} 


\section{8 \\ Concluding Remarks}

I have welcomed the opportunity to provide these reflections and have been surprised at the wide range of emotional responses I have experienced.

I have been excited by the process of documenting the extra-ordinary changes that are occurring in the Australian economy. In peace time, and over such a sustained period, Australia has never experienced such a large increase in income relative to so many other advanced economies. It now appears that Australian per capita income levels have increased about 25 per cent relative to the US and now exceed US levels.

I have been frustrated by the difficulty of tying together in a coherent and simple way the large changes that have been occurring. It is frustrating - in the context of such a large change in the terms of trade - not to understand better the theoretical and empirical links between trading gains, foreign ownership, RGDP, productivity and labour force changes. There is considerable theorizing and model building to be done.

I have been concerned at how limited has been the academic exploration of the future implications of the changes that are now occurring. For example, a significant fraction of RGDP and the employment growth being generated today is from a construction boom as new mines are built. This is a labour intensive activity. In the long run, when the construction stops, mining industry exports will employ very little labour. Does this imply that there will have to be a substantial reallocation of resources back to the industries that they previously left? Another worrying issue is that RGDI gains in living standards are being delivered differentially throughout the economy by increased import flows and changing relative prices in ways that are not fully understood. ${ }^{33}$

To conclude, I have been surprised that the simple question - what difference does it make whether the mining boom is generated by a price or volume increase - has

\footnotetext{
${ }^{33}$ Senior Australian policy bureaucrats, however, have been very active in explaining some of these ideas, see Assistant Governor P. Lowe (2009), (2011) and Governor of the Reserve Bank of Australia, G. Stevens (2010), D. Gruen (2006), Deputy Secretary and K. Henry (2007) Secretary of the Treasury. The Governor of the Reserve Bank has commented,

"On all the indications available we are living through an event that occurs maybe once or twice in a century" G. Stevens (2010).
} 
led to reflections that are so wide-ranging and untidy, perhaps an inevitable outcome of the rapid changes that are occurring. We are certainly living in extremely interesting times, but hopefully not in the Chinese sense of the phrase, although China is largely at the centre of these amazing changes. 


\section{References}

United Nations (1968), "A System of National Accounts”, in Studies in Methods, Ser. F, N0. 2, $3^{\text {rd }}$ Revn. New York; United Nations

United Nations (2008), System of National Accounts 2008, New York

Australian Bureau of Statistics (2001), "Real net national disposable income - a new national accounts measure", Australian National Accounts: National Income, Expenditure and Product (Cat. No. 5206.0), December Quarter

Australian Bureau of Statistics (2004), "The Terms of Trade and the National Accounts", in Australian National Accounts: National Income, Expenditure and Product, September Quarter 2004, Cat. No. 5206.0, ABS, Canberra

Australian Bureau of Statistics (2010), "Experimental Estimates of Industry Multifactor Productivity, Australia: Detailed Productivity Estimates,

Cat. No. 5206.0.55.002, ABS, Canberra

Australian Bureau of Statistics (2011), "Australian National Accounts; National income, Expenditure and Product”, Cat. No. 5206.0, ABS, Canberra, March

Australian Treasury (2002-03), Statement 4, "Australian Terms of Trade, Stronger and less Volatile", Budget Paper No. 1, Budget Strategy and Outlook, 2002-03, Canberra

Reserve Bank of Australia (2005), "Commodity Prices and the Terms of Trade", Reserve Bank of Australia Bulletin, April

Battersby, B. (2006), "Does Distance Matter? The Effect of Geographic Isolation on Productivity Levels", OECD Economic Studies, No 42

Blundell-Wignall, A. and R. G. Gregory (1990), "Exchange Rate Policy in Advanced Commodity - Exporting Countries. The Case of Australia and NZ", OECD Economic Development, Working Paper 83, OECD Publishing

Chen V. and A. Gupta, A. D. Therrien, G. Lervanon and Bart van Ark (2010), "Recent Productivity Developments in the World Economy: An Overview from The Conference Board Total Economy Database", International Productivity Monitor, The Conference Board.

Coleman, W. (2008), "Gauging Economic Performance under Changing Terms of Trade Real Gross Domestic Income or Real Gross Domestic Product", Economic Papers, 27 (4) Dec. p1-1-116 
Corden, W. M. (1984), "Booming Sector and Dutch Disease Economic Survey and Reconcilation”, Oxford Economic Papers, Vol. 33, 59-380

Corden, W. M. and P. Neary (1982), "Booming Sector and De-Industrialization in a Small Open Economy”, Economic Journal, 92 (Dec) 825 -45

Davis, G. and J. Rahman (2006), "Perspectives on Australia's Productivity Prospects", Treasury Working Paper, 2006-04, September

Diewert. W. E. and C. J. Morrison (1986), "Adjusting Output and Productivity indexes for Changes in the Terms of Trade”, The Economic Journal, Vol. 96 No 383 Sept.

Feenstra, R. C. and A. Heston, M. P. Timmer and H. Deng (2009), "Estimating Real Production and Expenditure Across Nations: A Proposal for Improving the Penn World Tables", The Review of Economics and Statistics, Feb, Vol.91 No.1, pp 201-212

Feenstsra, R. C. and B. S. Mandel, M. B. Reinsdorf and M. J. Slaughter (2009). "Effects of Terms of Trade Gains and Tariff Changes on the Measurement of US Productivity Growth", NBER Working Paper, 15592, Dec

Forsyth, P. J. and J. P. Kay (1981), “Oil Revenues and Manufacturing Output”, Fiscal Studies, July 9-17

Gruen. D. (2006), “A tale of two terms of trade booms”, Economic Roundup, Treasury, Summer 21-34

Gruen, F. H. (1975), “The 25\% Tariff Cut Was it a Mistake?”, The Australian Quarterly, Vol. 47 No 2, June

Gregory, R. G. (1976), "Some Implications of the Growth of the Mineral Sector", Australian Journal of Agricultural Economics, 20 (August), 71-91

Gregory, R. G. and P. Frijters (2006), “From Golden Age to Golden Age, Australia's Great Leap Forward, The Economic Record, Vol. 82 (257), 207 -224, 06

Gregory, R. G. (1988), “An Overview” in R. G. Gregory and N.G. Butlin, (eds) Recovery from the Depression Australia and the World Economy in the 1930s, Cambridge University Press, Melbourne

Gregory, R. G. (1993), “Aspects of Australian and the US Living Standards; the Disappointing Decades 1970 -1990”, Economic Record, Vol. 69 (204) 61-76 March

Henry, K. (2007), "Achieving and Maintaining Full Employment", The 2007 Sir Roland Wilson Foundation Lecture, Canberra, Aug 
Kay, J. and P. J. Forsyth (1980), "The Economic Implication of North Sea Oil Revenues", Fiscal Studies, Vol. No 3 July

Kohli, Ulrich R. (2004), "Real GDP, real domestic income and terms-of-trade changes", Journal of International Economics, January, 62

Long, N.V. (1983), "On the Effect of a Booming Export Industry on the Rest of the Economy", Economic Record, 59, March, 57-60

Lowe, P. (2009), "The Growth of Asia and Some Implications for Australia", Reserve Bank of Australia, Bulletin Nov

Lowe, P. (2011), "Changing Relative Prices and the Structure of the Australian Economy", Address to the Australian Industry Group, $11^{\text {th }}$ Annual Economic Forum, 8 March

Macdonald, R. (2010), "Real Gross Domestic Income Relative Prices and Economic Performance Across the OECD", Review of Income and Wealth, Sept. Vol. 5, Issue 3, $449-650$

Maddock, R. and I. McLean (1983), "Supply Side Shocks, The Case of Australian Gold", The Journal of Economic History, 44(4), 1047 -1067

Magud, N. and S. Sosa (2010), "When and Why Worry About Real Exchange Rate Appreciations? The Missing Link between Dutch Diseases and Growth", IMF Working Paper, Dec. WP/10/27

Nicholson, J. L. (1960), "The Effect of international trade on the measurement of real national income", Economic Journal. 70, 608-612

Rahman J (2005), “Comparing Australian and United States productivity”, Economic Roundup, Autumn, Commonwealth of Australia, Canberra

Reinsdorf, M. B. (2010), “Terms of Trade Effects, Theory and Measurement, The Review of Income and Wealth, Series 56 Special Issue, June

Salter, W. E. G. (1959), "Internal and External Balance; The Role of Price and Expenditure Effects", Economic Record, Vol. 35 August, 225-230

Shann, E. W. (1983), "Policy Issues in Mineral Sector Growth, A Keynesian Model", Discussion Paper No. 60 December Centre for Economic Policy Research, Australian National University, Canberra

Silver, M. and K. Mahdavy (1989), "The Measurement of a Nation's Terms of Trade Effect and Real National Disposable Income within a National Accounting Framework", Journal of the Royal Statistical Society, Series A, Vol. 152, No. 1 87-107 
Snape, R. (1977), "Effects of Mineral Development and the Economy", Australian Journal of Agricultural Economics Dec. 147-56

Stevens, G. (2010), “The Challenge of Prosperity", Address to the Committee for the Economic Development of Australia (CEDA), Melbourne, 29 Nov.

Stoeckel, A. (1979), "Some Equilibrium Effects of Mining Growth on the Economy", Australian Journal of Agricultural Economics, 21 April 1-22

Swan, T. W. (1960), "Economic Control in a Dependent Economy", The Economic Record, Vol. 36, 57-66

Swan, W., Treasurer of the Commonwealth of Australia (2010), Australia to 2050:

Future Challenges, Canberra, January

Taussig, F. W. (1927), International Trade, The Macmillan Co., New York

Topp, V. L. Soames, D. Parham, and H. Bloch (2008), "Productivity in the Mining Industry; Measurement and Interpretation", Productivity Commission Staff Working Paper, Dec

Turner, D. (2006), "Should Measures of Fiscal Stance be adjusted for Terms of Trade Effects”, Economic Department Working Paper, No 519, OECD Paris

Warr, P. (2006), "The Gregory Thesis Visits the Tropics", The Economic Record, Vol. (82) $257,177-194$

Wilkie and T McDonald (2008), "Economic geography and economic performance in Australia", Economic Round-up Issue No. 3 The Treasury, Australian Government

Wilson, R. (1931), Capital Imports and the Terms of Trade Examined in the Light of 60 Years of Australian Borrowing, Melbourne University Press, Melbourne 
Figure 1:

Commodity Prices

Index 1982=100, Based on 2008/09 weights

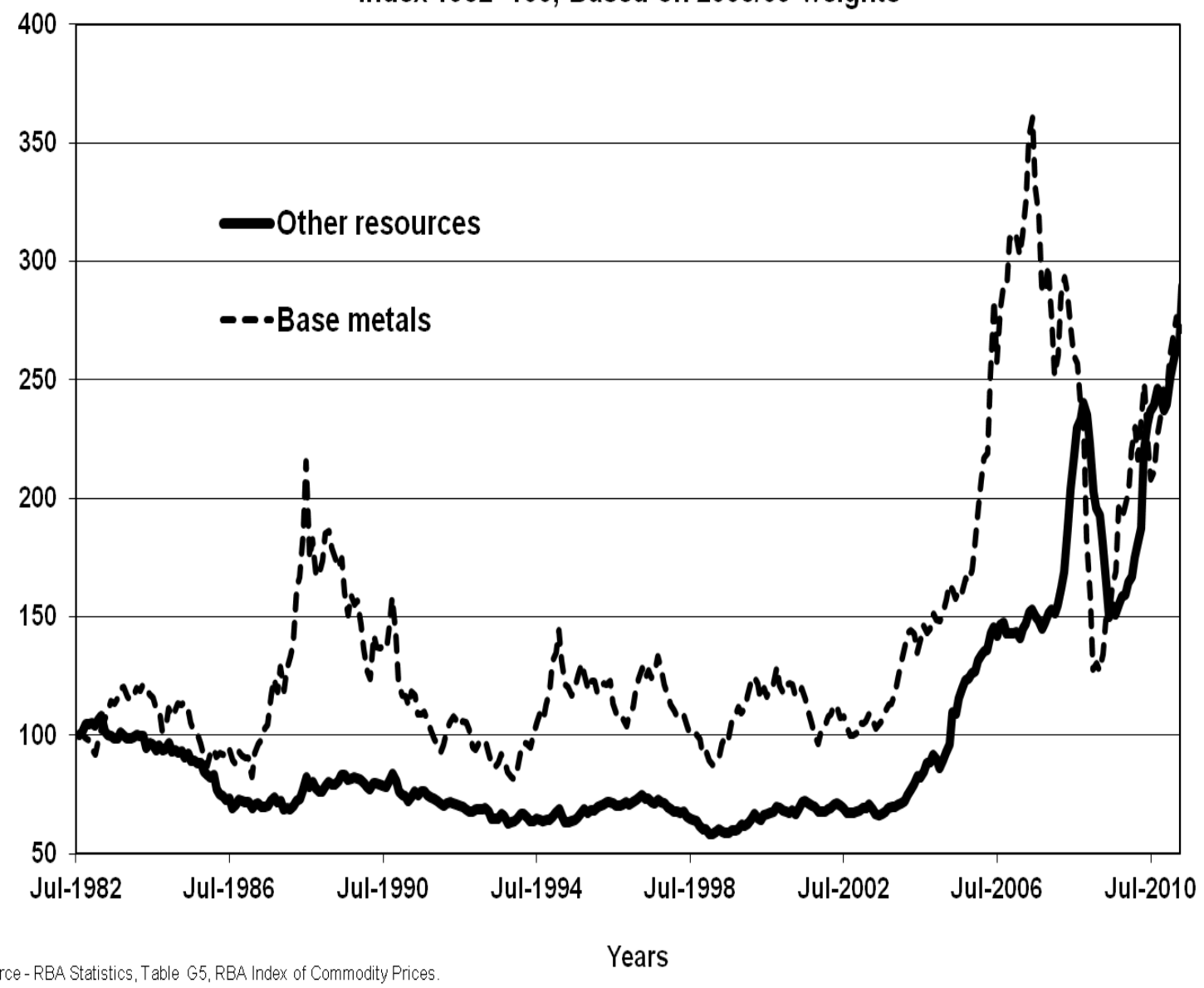


Figure 2:

Terms of Trade, Australia

Index 1959=1.0

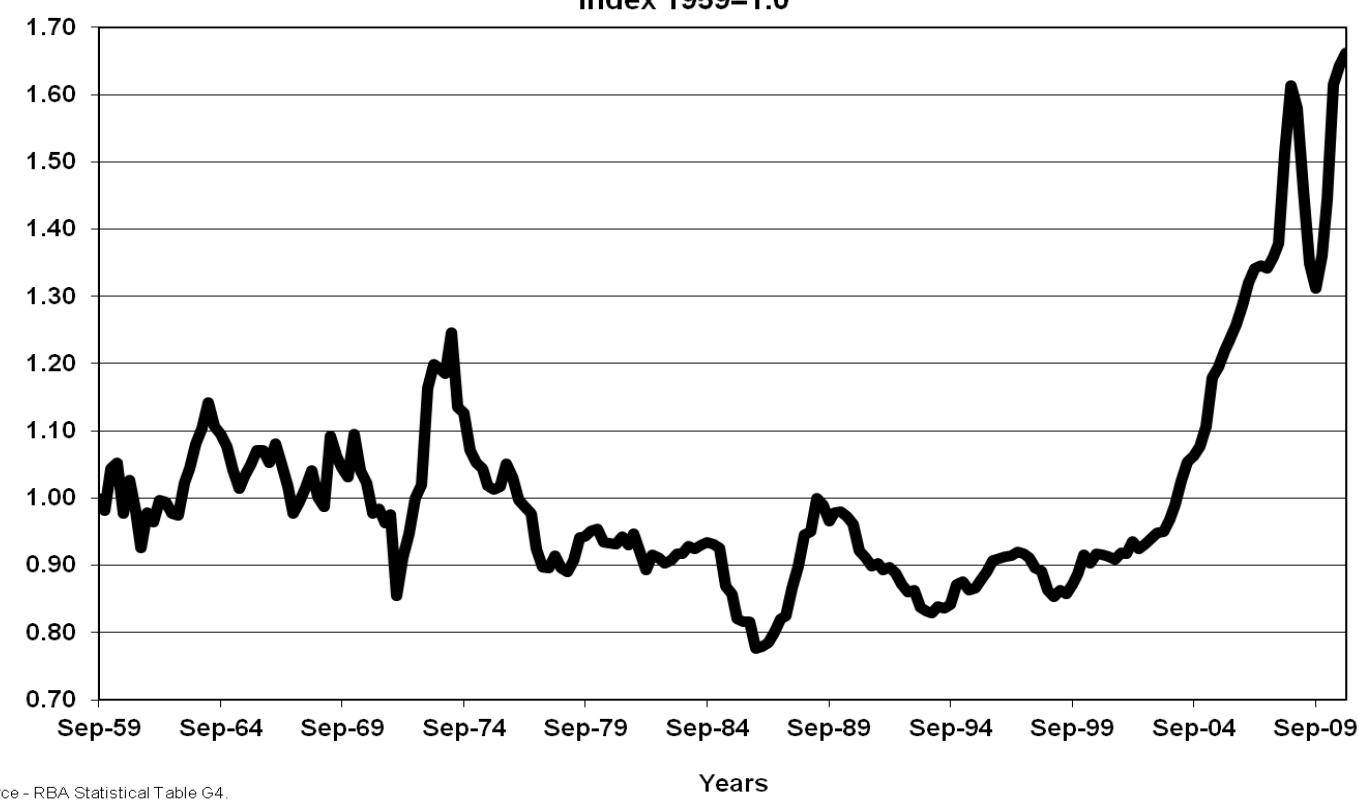

Figure 3:

Volume and Value \$m Ratios (sa), 1959=1.0

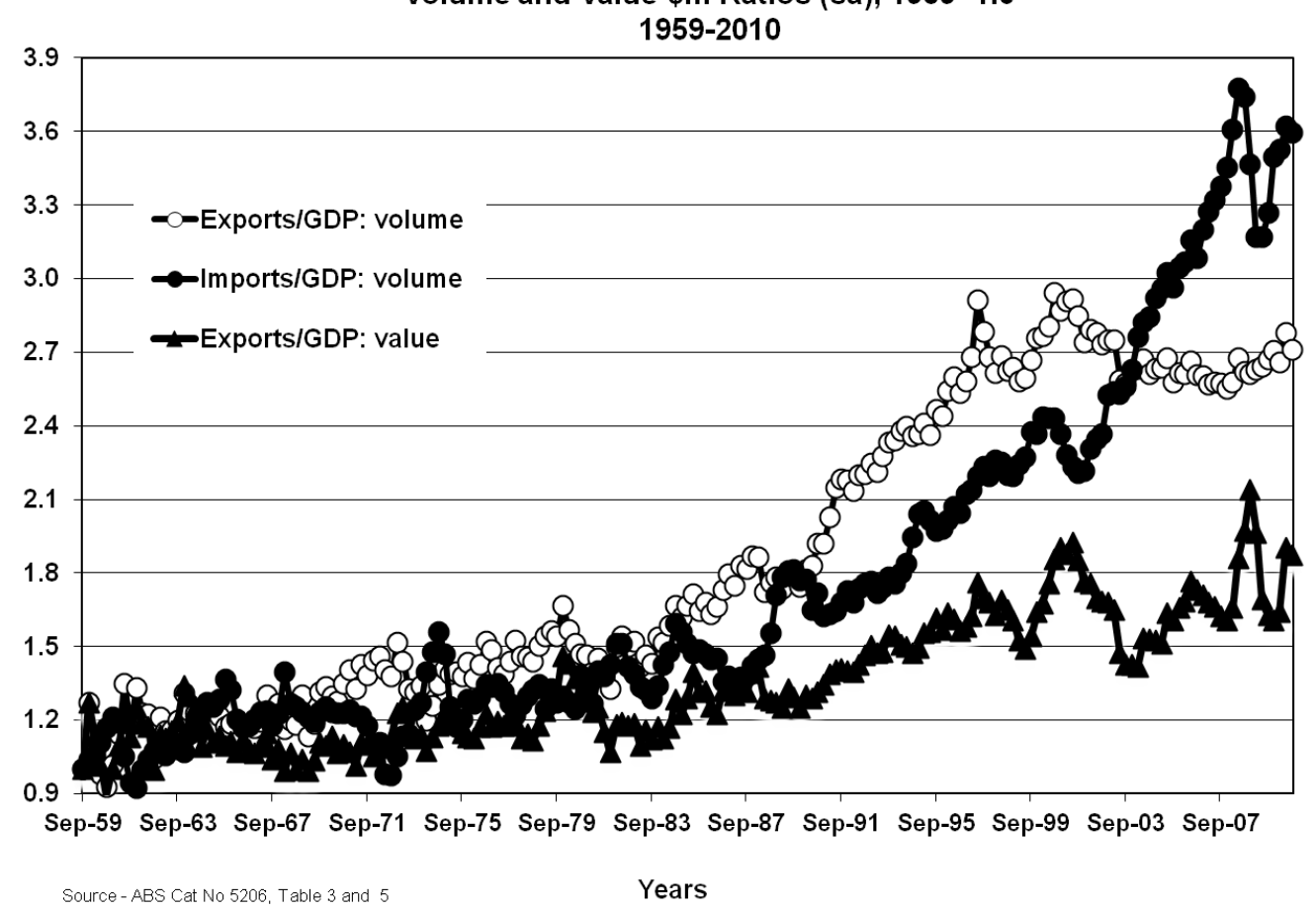


Figure 4: Labour productivity and living standard measures per capita, Australia, $1959=1$

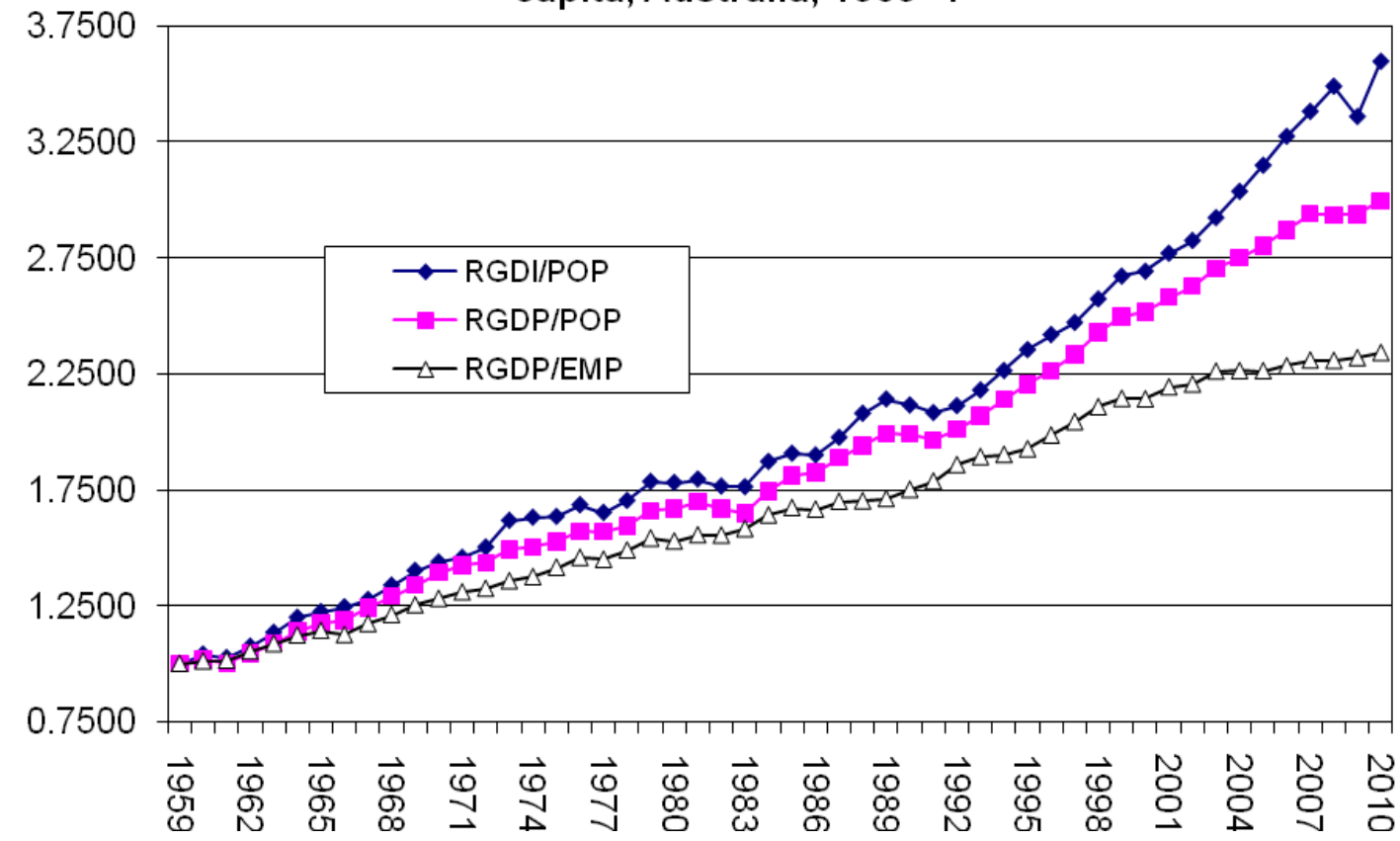

Figure 5:

Australia to US Ratio, per capita

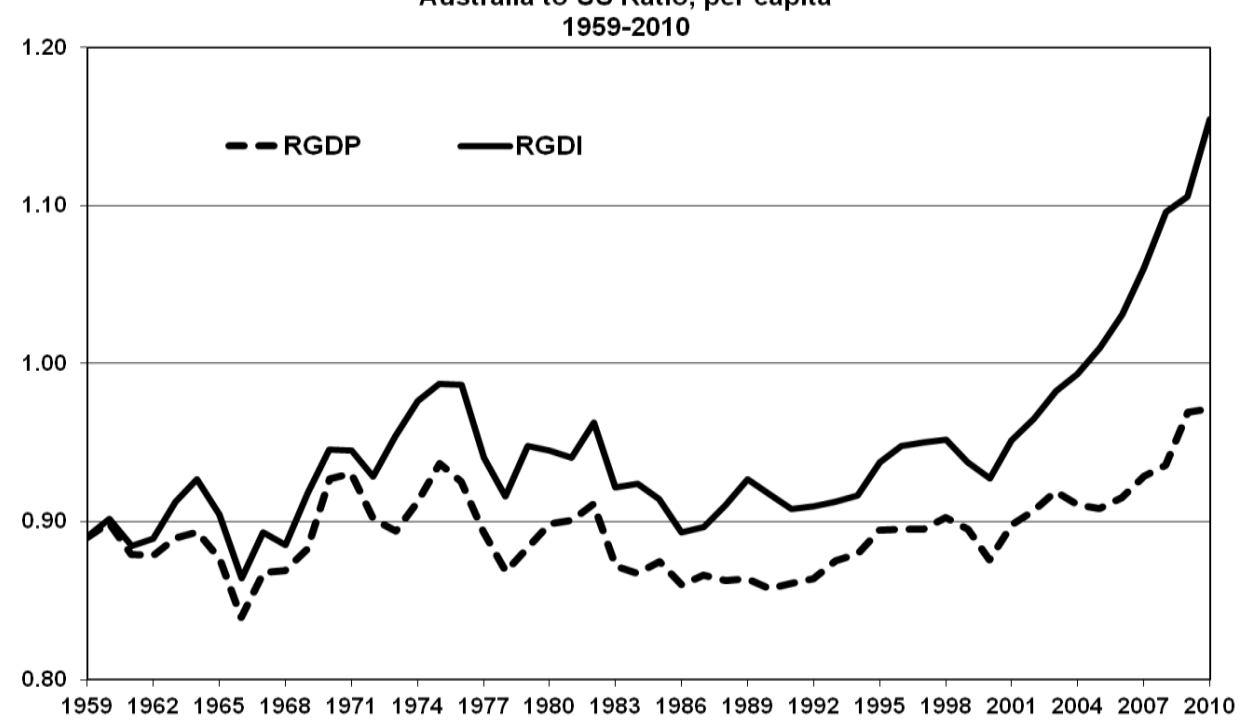

Source - The Conferencoe Board Total Economy Databese, January 2011. 2010 EKS\$ Years 
Figure 6:

Australia to US Ratios, $1959=1.0$

1959-2010

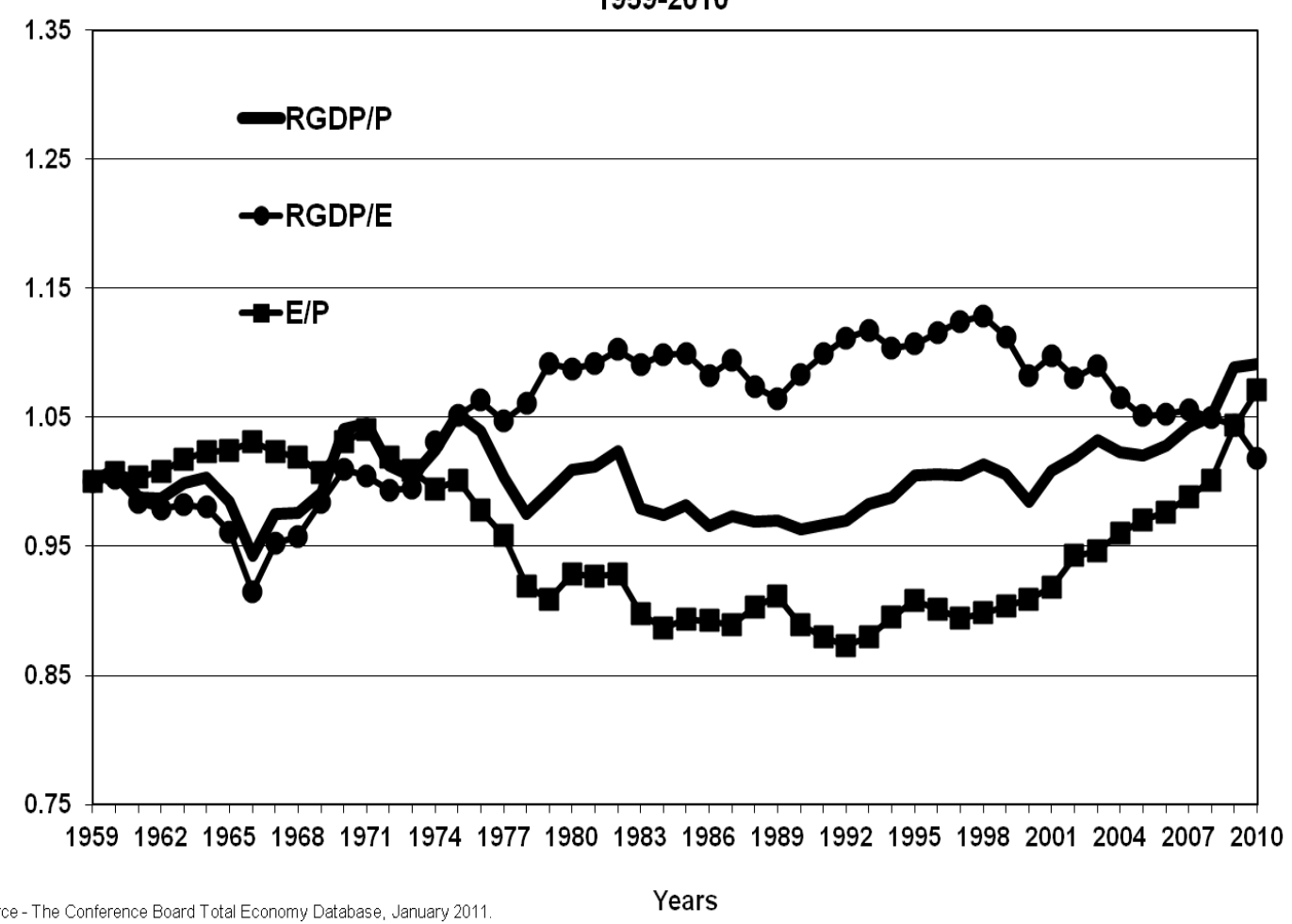

Figure 7:

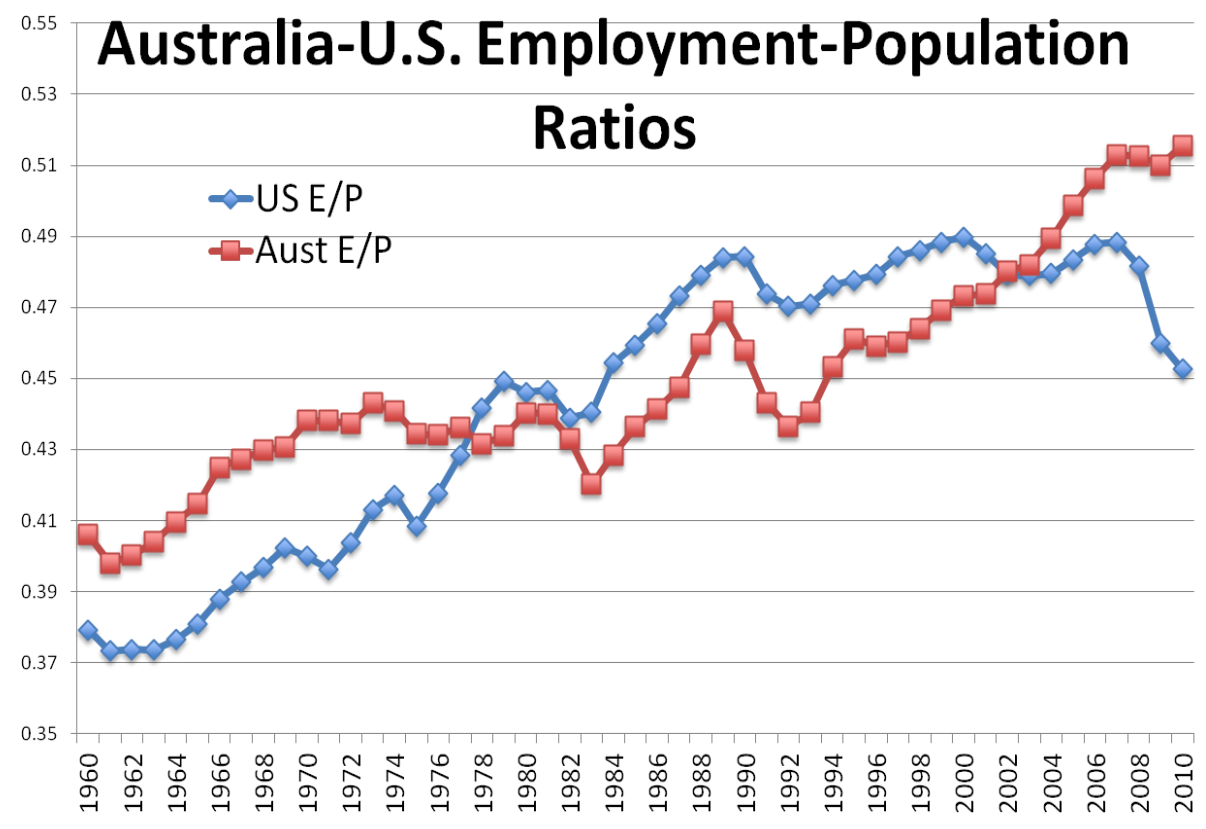


Table 1 Mining Share of Total: Profit, Compensation of Employees and Value Added

\begin{tabular}{ccccc}
\hline \hline & & Current price share & & Constant price \\
& & $\begin{array}{c}\text { Total } \\
\text { Share }\end{array}$ & \\
1992 & Profit & $\begin{array}{c}\text { Compensation } \\
\text { of Employees }\end{array}$ & Value Added & Value Added \\
2002 & 8.3 & 2.7 & 5.1 & 10.7 \\
2004 & 9.2 & 2 & 5.3 & 10.3 \\
2006 & 1.3 & 2.1 & 4.4 & 9.3 \\
2008 & 14.3 & 2.4 & 7.4 & 9.4 \\
2010 & 14.9 & 2.7 & 7.8 & 9.7 \\
\hline \hline
\end{tabular}

